\title{
Aspects of treatment for posterior heel pain in young athletes
}

This article was published in the following Dove Press journal:

Open Access Journal of Sports Medicine

3 December 2010

Number of times this article has been viewed

\author{
Thomas Elengard' \\ Jón Karlsson' \\ Karin Grävare Silbernagel ${ }^{2}$ \\ 'Department of Orthopaedics, \\ Institute of Clinical Sciences at \\ Sahlgrenska Academy, University \\ of Gothenburg, Sahlgrenska \\ University Hospital, Gothenburg, \\ Sweden; ${ }^{2}$ Department of Mechanical \\ Engineering, University of Delaware, \\ Newark, Delaware, USA
}

Correspondence: Karin Grävare Silbernagel

Department of Mechanical Engineering, University of Delaware, 126 Spencer Laboratory, Newark, DE 19716, USA

$\mathrm{Tel}+\mid 302$ 83| 242।

$\mathrm{Fax}+13028313619$

Email kgs@udel.edu
Abstract: Posterior heel pain occurs in young athletes involved in running and jumping. Due to the pain, the child often limits his/her physical activity level, with a possible negative effect on health and well-being. Although numerous research studies have examined the cause and treatment of heel and Achilles tendon pain in adults, there are no randomized clinical trials on treatment in children and adolescents. Therefore, there is limited evidence for how to treat young athletes with this type of complaint. The purpose of this review was to analyze critically and summarize the literature in regards to the cause and treatment of posterior heel pain in young athletes. The various diagnoses and clinical presentations relating to posterior heel and Achilles tendon pain are discussed. The theory and mechanism behind various recommended treatment strategies are also reviewed in the context of use in the young athlete. In summary, it is important to perform a thorough evaluation of each young athlete with heel pain to determine the appropriate diagnosis and to treat the deficits found and allow for a gradual progression to training. However, the recommendations at this time are based on clinical experience and a few retrospective studies, so further well designed prospective studies with validated outcome measures are urgently needed for the young athlete.

Keywords: Sever's disease, apophysitis, tendinitis, tendinopathy, child, adolescent

\section{Introduction}

Physical activity on a regular basis is recommended for maintaining and achieving good health. Despite this knowledge, it can be seen that children are progressively becoming more sedentary in today's culture. However, through sports participation, children can maintain an active lifestyle. On the other hand, sport injuries are common in young athletes and can cause decreased activity levels or even force the child to cease his/her sport. ${ }^{1}$ The foot and ankle area is one of the most injured parts of the body in the adolescent athlete, and accounts for up to $30 \%$ of visits to sports medicine clinics. ${ }^{1-3}$ Active children and adolescents often complain of pain in the posterior aspect of the heel. ${ }^{4,5}$ Although numerous research studies have examined the cause and treatment of Achilles tendon pain, there are few studies of treatment in children and adolescents. ${ }^{6-9}$ For adults, eccentric exercise and continued activity have been shown to be successful treatments for overuse injuries to the Achilles tendon instead of rest and/or anti-inflammatory medications. ${ }^{6,7,10,11}$ These methods may, in the clinical setting, be recommended for children with posterior heel pain. However, there are no studies that have evaluated this type of treatment in this patient group. Opposite to adults, children have a relative weakness in their growing bone as compared with the ligament and tendon structures surrounding it in the heel. ${ }^{2,3,5}$ Therefore, the use of adult treatment guidelines may be inappropriate for children. This 


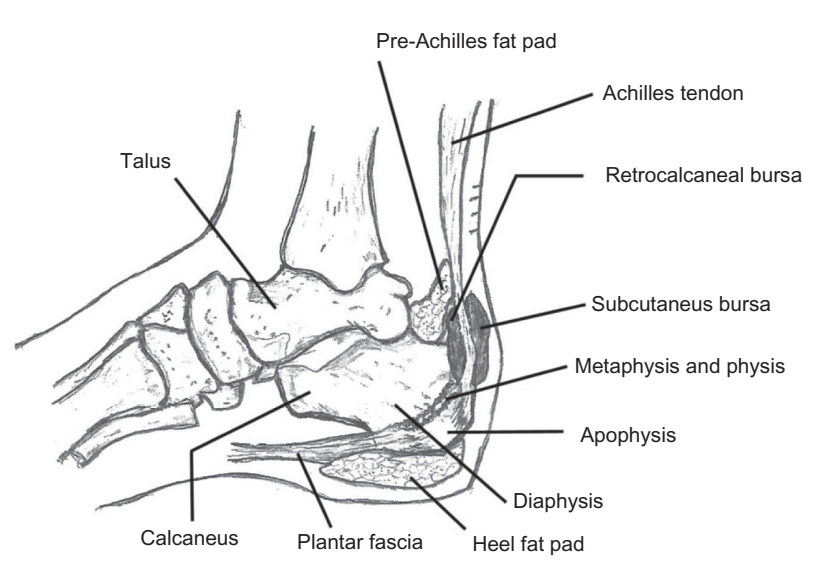

Figure I Important structures of the hindfoot.

review aims to review critically and summarize the literature in regards to the cause and treatment of posterior heel pain in young athletes.

\section{Anatomy (Figure I)}

The hind foot is composed of the talus and the calcaneus bones. ${ }^{3}$ The calcaneus develops in a manner comparable with long bones, thus forming a diaphysis (the primary ossification center), a metaphysis, a physis, and an apophysis (the secondary ossification center). ${ }^{1,12}$ However, the difference, as compared with most long bones, is slower growth and fewer proliferation cells in the calcaneus. ${ }^{4}$ Because of strong tensile forces, there are increased physis-traversing longitudinal collagen fibers in the calcaneus. ${ }^{4,13}$ The apophysis is located in the posterior end of the calcaneus and serves as an attachment site for the Achilles tendon superiorly and the plantar fascia inferiorly. ${ }^{3}$ The pre-Achilles fat pad is positioned between the superior border of the calcaneus and the Achilles tendon. ${ }^{14}$ Its biomechanical function is not fully understood, but a number of tasks, including reduction of pressure change within the osteotendinous junction, lubrication of the subtendinous region, and removal of debris from within the retrocalcaneal bursa, have been suggested. ${ }^{14}$

\section{Potential causes and diagnoses}

In the literature, various causes for posterior heel and Achilles tendon pain in young athletes are described. ${ }^{15,16}$ The various possible diagnoses are presented in Tables 1-4., ${ }^{3,16-18}$

Acute injuries (Table 1) have a rapid onset and usually a well-defined traumatic event. Both children and adults can be subjected to acute injuries, including strains, distortions, contusions, ruptures, and fractures in much the same way. However, due to different tissue properties during growth, the same mechanism of injury can result in different types of damage in children/adolescents as compared with adults.

Overuse injuries (Table 2) have been defined as chronic injuries related to constant repetitive stress without adequate recovery time. ${ }^{19}$ Overuse is considered to be a common cause of heel pain in the growing athlete as well as in the adult. ${ }^{15,20}$ This type of injury can strike different structures, including the bone, Achilles tendon, or a bursa, depending on which is the weakest link when exposed to different kinds of stresses. As long as the physis of the calcaneal bone in adolescents has not fused, the apophysis is a frequent target for overuse injuries. ${ }^{5}$ This differs from adults, where instead the Achilles tendon is a common site of overuse injury. ${ }^{21}$

The third category is injuries related to growth. Here the injury is related to abnormal development from accessory ossification centers or from bony coalition ${ }^{3}$ (Table 3 ). Accessory ossicles usually appear at $8-10$ years of age and fuse some years after their formation. ${ }^{3}$ If they do not fuse, they become symptomatic. ${ }^{3,15} \mathrm{~A}$ coalition is a fusion between two or more bones. ${ }^{3}$ They consist of bony, fibrous, or cartilaginous tissues, and can therefore act as their own ossification center. ${ }^{3}$ They become painful when they ossify, especially in highly active young athletes who place their tissue under a lot of stress. ${ }^{3}$ This type of injury exclusively affects children and is not related to sports. But there is a possibility that they could be discovered when causing problems for the active child, and are therefore important to bear in mind.

Table I Acute injuries in young athletes with posterior heel pain

\begin{tabular}{llll}
\hline Diagnosis & Presentation & Clinical findings & Radiology \\
\hline $\begin{array}{l}\text { Contusion } \\
\text { Achilles tendinitis/partial }\end{array}$ & $\begin{array}{l}\text { Heel impact, local pain, } \\
\text { possible bruise }\end{array}$ & $\begin{array}{l}\text { Ecchymosis, swelling, } \\
\text { tenderness }\end{array}$ & $\begin{array}{l}\text { Normal, if no signs of } \\
\text { fracture; MRI and/or US } \\
\text { may be helpful } \\
\text { Paratendonitis }\end{array}$ \\
$\begin{array}{lll}\text { History of trauma } \\
\text { Fracture of the calcaneus }\end{array}$ & $\begin{array}{l}\text { Pain on palpation } \\
\text { overuse injury } \\
\text { History of trauma, often } \\
\text { fall with landing on heel }\end{array}$ & $\begin{array}{l}\text { Possible crepitus in the } \\
\text { acute phase } \\
\text { Pain on palpation at } \\
\text { fracture site, often major } \\
\text { swelling }\end{array}$ & - \\
\hline
\end{tabular}

Abbreviations: MRI, magnetic resonance imaging; US, ultrasound; CT, computed tomography. 
Table 2 Overuse injuries in young athletes with heel pain

\begin{tabular}{|c|c|c|c|}
\hline Diagnosis & Presentation & Clinical findings & Radiology \\
\hline $\begin{array}{l}\text { Sever's disease } \\
\text { (calcaneal apophysitis) }\end{array}$ & $\begin{array}{l}\text { Athletes in growth spurt } \\
\text { participating in running activities } \\
\text { may be unilateral but more } \\
\text { often bilateral pain which } \\
\text { increases with activity }\end{array}$ & $\begin{array}{l}\text { Tight heel cords, tenderness } \\
\text { on palpation at the } \\
\text { insertion of the Achilles } \\
\text { tendon pain over nodules } \\
\text { at the insertion site }\end{array}$ & $\begin{array}{l}\text { Sclerosis and fragmentation of the } \\
\text { calcaneal apophysis radiology may } \\
\text { be suggestive but not diagnostic }\end{array}$ \\
\hline $\begin{array}{l}\text { Achilles tendinopathy } \\
\text { (tendinitis, } \\
\text { paratendinopathy, } \\
\text { tendinosis) }\end{array}$ & $\begin{array}{l}\text { Stiffness of tendon which } \\
\text { progresses to pain with } \\
\text { continued activity }\end{array}$ & $\begin{array}{l}\text { Tenderness/thickening on } \\
\text { palpation of tendon; tight } \\
\text { heel cords, crepitus or } \\
\text { swelling over Achilles tendon }\end{array}$ & $\begin{array}{l}\text { US shows thickening of tendon and } \\
\text { possibly intratendinous tears; MRI } \\
\text { shows intratendinous tears, thickening } \\
\text { and/or degeneration of tendon }\end{array}$ \\
\hline Retrocalcaneal bursitis & $\begin{array}{l}\text { Pain, with localized } \\
\text { swelling anterior to } \\
\text { the Achilles tendon }\end{array}$ & $\begin{array}{l}\text { Tenderness on palpation } \\
\text { and/or swelling in the } \\
\text { retrocalcaneal area }\end{array}$ & $\begin{array}{l}\text { In some cases posterior superior } \\
\text { enlargement of the calcaneus; } \\
\text { US and MRI may show bursal swelling }\end{array}$ \\
\hline $\begin{array}{l}\text { Haglund's syndrome } \\
\text { (runner's bump, calcaneal } \\
\text { exostosis, pump bump) }\end{array}$ & $\begin{array}{l}\text { Enlarged posterosuperior } \\
\text { calcaneal prominence }\end{array}$ & $\begin{array}{l}\text { Subcutaneous Achilles } \\
\text { bursa may be tender to } \\
\text { palpation; posterosuperior } \\
\text { calcaneal prominence }\end{array}$ & $\begin{array}{l}\text { Plain radiograph; pseudoexostosis } \\
\text { localized between the calcaneus } \\
\text { and the Achilles tendon }\end{array}$ \\
\hline $\begin{array}{l}\text { Stress fracture of } \\
\text { the calcaneus }\end{array}$ & Pain, swelling at fracture site & $\begin{array}{l}\text { Pain with compression of } \\
\text { the calcaneus; pain on } \\
\text { palpation at fracture site }\end{array}$ & $\begin{array}{l}\text { Plain radiograph: normal (in most } \\
\text { cases) or fine fracture line; bone } \\
\text { scan or MRI (preferable) if plain } \\
\text { radiographs are negative }\end{array}$ \\
\hline Plantar fasciitis & $\begin{array}{l}\text { Often unilateral, pain/local } \\
\text { tenderness over proximal } \\
\text { medial arch/heel with weight } \\
\text { bearing, morning pain }\end{array}$ & $\begin{array}{l}\text { Tenderness on palpation } \\
\text { over the medial calcaneal } \\
\text { tubercle at insertion of plantar } \\
\text { fascia; often tight heel cords }\end{array}$ & $\begin{array}{l}\text { Radiographs might show anterior } \\
\text { inferior calcaneal spur; MRI and/or } \\
\text { US not needed for diagnostic } \\
\text { evaluation }\end{array}$ \\
\hline Heel fat pad syndrome & $\begin{array}{l}\text { Walking after rest or barefoot } \\
\text { painful, pain increases with } \\
\text { activity; often overweight patients }\end{array}$ & $\begin{array}{l}\text { Pain on palpation of heel pad; } \\
\text { tiptoe standing/walking may } \\
\text { cause pain relief }\end{array}$ & Not helpful \\
\hline Tarsal tunnel syndrome & $\begin{array}{l}\text { Burning pain, with possible medial } \\
\text { or foot sole paresthesia that increases } \\
\text { with weight bearing; symptoms may } \\
\text { coexist with plantar fasciitis }\end{array}$ & $\begin{array}{l}\text { Positive Tinel's sign; often } \\
\text { hyperpronated or flat feet }\end{array}$ & $\begin{array}{l}\text { Radiographs normal and are not } \\
\text { helpful; electromyography/nerve } \\
\text { conduction test if needed }\end{array}$ \\
\hline
\end{tabular}

Abbreviations: MRI, magnetic resonance imaging; US, ultrasound; CT, computed tomography.

Even though the most common causes of heel pain among young athletes are acute and overuse injuries, there are also some rare conditions that have to be considered. These are tumors, infections, and systemic conditions, as presented in Table 4.

\section{Occurrence of posterior heel and Achilles tendon pain in young athletes}

Year-round training and longer competitive seasons, in combination with training errors, poorly fitting equipment, growing cartilage, and muscle imbalance, are proposed explanations for the increasing number of overuse injuries

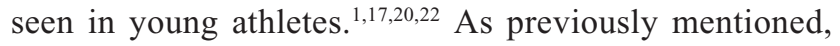
the foot and ankle area is one of the most injured parts of the body in young athletes, and can account for up to $30 \%$ of visits to sports medicine clinics. ${ }^{1-3}$ Sports that include running and jumping are often associated with posterior heel and Achilles tendon pain in young athletes. ${ }^{18,22}$ It has been found that approximately $87 \%$ of young athletes with posterior heel and Achilles tendon injury were involved

Table 3 Hind foot injuries related to growth

\begin{tabular}{|c|c|c|c|}
\hline Diagnosis & Presentation & Clinical findings & Radiology \\
\hline Os trigonum & $\begin{array}{l}\text { Young athletes with } \\
\text { posterolateral ankle pain; } \\
\text { worse with tiptoe walking }\end{array}$ & $\begin{array}{l}\text { Posterolateral ankle pain } \\
\text { that is reproducible on } \\
\text { palpation and active or } \\
\text { passive plantar flexion }\end{array}$ & $\begin{array}{l}\text { Radiograph: an ossicle is } \\
\text { seen posterior to the } \\
\text { talus, between the } \\
\text { calcaneus and distal tibia }\end{array}$ \\
\hline Talocalcaneal coalition & $\begin{array}{l}\text { Pain increases with } \\
\text { activity; often a history } \\
\text { of lateral ankle sprains }\end{array}$ & $\begin{array}{l}\text { Examination shows decreased } \\
\text { hind foot motion; rigid varus } \\
\text { and absence of heel varus on tiptoe }\end{array}$ & $\begin{array}{l}\text { CT: union of tarsal } \\
\text { bones; four-corner syndrome }\end{array}$ \\
\hline
\end{tabular}

Abbreviation: CT, computed tomography. 
Table 4 Infectious conditions, systemic conditions, and tumors

\begin{tabular}{|c|c|c|c|}
\hline Diagnosis & Presentation & Clinical findings & Radiology \\
\hline $\begin{array}{l}\text { Soft tissue infection } \\
\text { Abscess } \\
\text { Calcaneal osteomyelitis }\end{array}$ & $\begin{array}{l}\text { Fever; night pain; } \\
\text { redness/swelling }\end{array}$ & $\begin{array}{l}\text { Soft tissue swelling; } \\
\text { tenderness on palpation }\end{array}$ & $\begin{array}{l}\text { Radiograph: normal or } \\
\text { soft tissue swelling }\end{array}$ \\
\hline $\begin{array}{l}\text { Juvenile rheumatoid arthritis } \\
\text { Reiter's syndrome } \\
\text { Ankylosing spondylitis }\end{array}$ & $\begin{array}{l}\text { Disease-specific and } \\
\text { plantar fasciitis-like symptoms; } \\
\text { morning stiffness, joint } \\
\text { swelling and pain; often } \\
\text { bilateral symptoms }\end{array}$ & $\begin{array}{l}\text { Complete history and } \\
\text { physical examination } \\
\text { with blood analysis for } \\
\text { rheumatoid disease, such } \\
\text { as ESR, RF, HLA B27 }\end{array}$ & $\begin{array}{l}\text { Radiograph: large, fluffy } \\
\text { heel spurs and erosions of the } \\
\text { posterosuperior cortex of the } \\
\text { calcaneus; MRI is helpful for early } \\
\text { joint erosion and synovitis. }\end{array}$ \\
\hline $\begin{array}{l}\text { Osteoid osteoma } \\
\text { Osteochondroma } \\
\text { Chondroblastoma } \\
\text { Bone cyst }\end{array}$ & $\begin{array}{l}\text { Fever, night pain; pain } \\
\text { of long duration }\end{array}$ & $\begin{array}{l}\text { Complete history with a } \\
\text { review of systems } \\
\text { CBC, ESR }\end{array}$ & $\begin{array}{l}\text { Radiograph may show } \\
\text { radiolucent mass; bone } \\
\text { scan may be useful; MRI } \\
\text { always indicated in case } \\
\text { of tumor suspicion }\end{array}$ \\
\hline
\end{tabular}

Abbreviations: MRI, magnetic resonance imaging; ESR, erythrocyte sedimentation rate; RF, rheumatoid factor; CBC, complete blood count; HLA, human leukocyte antigen.

in running and jumping sports. ${ }^{18,22}$ Twenty-one percent of these athletes were runners and $18 \%$ were soccer players, but also nonrunning sports like hockey (5\%) were represented. ${ }^{18,22}$ Apophyseal problems are reported to affect $18 \%$ of the pediatric and adolescent sports population, and $90 \%$ of these injuries occur in patients whose epiphyses are still open. ${ }^{23}$ This can be compared with adults, where this type of injury is reported to occur in $0.3 \%$ of physically active adults. ${ }^{23}$ Most apophyseal problems in young patients are suggested to be caused by Sever's disease. ${ }^{23} \mathrm{In}$ a retrospective study of 351 children aged $7-16$ years, $11.3 \%$ were reported to have calcaneal pain and $3.8 \%$ to have Achilles pain. ${ }^{24}$ When these children were divided into subgroups based on their activity level, it was found that, in the active children, $17.6 \%$ had Achilles pain and $6.1 \%$ had calcaneal pain, and in the passive (inactive) group, 9.9\% had Achilles pain and $6.8 \%$ had calcaneal pain. ${ }^{24}$ This indicates that even inactive children are vulnerable to these types of injuries.

\section{Heel pain in the growing athlete: a complex problem?}

Sever's disease is described by many as the most common cause of heel pain among athletes during their growth spurt, and is by far the most described overuse injury in the literature for young athletes with posterior heel pain..$^{18,20,23,25} \mathrm{On}$ the other hand, there are studies indicating that the problem might be more complex and involve other structures., $422,24,26,27$ Kvist and Heinonen ${ }^{26}$ found, for example, in a retrospective questionnaire of 67 patients under 16 years of age with Sever's disease, that simultaneous pain in the Achilles tendon region was present in $10 \%$ of the patients. Several other authors have also described that tenderness in the Achilles tendon or in the area of its insertion are not uncommon in patients with Sever's disease. . $^{1,16,19,23,25,28-32}$ A retrospective study involving 445 sport patients aged $8-19$ years reported that $21 \%$ had calcaneal apophysitis and $20 \%$ had Achilles tendinitis (also known as Achilles tendinopathy) as a primary diagnosis. ${ }^{22}$ Furthermore, this study found that in the group of 88 patients with a primary diagnosis of Achilles tendinitis, calcaneal apophysitis, and plantar fasciitis were common concurrent problems. ${ }^{22}$ On the other hand, in the group of 92 patients with a primary diagnosis of calcaneal apophysitis, many also had symptoms from the Achilles tendon or plantar fascia region. ${ }^{22}$ Micheli and Fehlandt ${ }^{4}$ speculate based on their studies ${ }^{4,22}$ and clinical experience that the calcaneal apophysitis and Achilles tendinitis occur in different stages of growth, and in the intermediate stage there are patients with both conditions. It appears that the apophysis is more at risk during periods of rapid growth, whereas the tendons are more at risk during periods of stable or slow growth, thus demonstrating a more adult-like injury pattern. ${ }^{4}$ Another example of coexisting problems with calcaneal apophysitis is described by Hosgören et al. ${ }^{33}$ They examined 21 patients diagnosed with Sever`s disease using ultrasonography and found two children with coexisting retrocalcaneal bursitis. ${ }^{33}$

The diagnosis of Sever's disease has also been questioned, and it is suggested that instead of being an apophysitis it may be a metaphyseal trabecular stress fracture. ${ }^{34}$ Ogden et al ${ }^{14}$ examined heel pain nonresponsive to the usual treatment in 14 patients using magnetic resonance imaging (MRI) and found signal changes within the metaphysis. These patients responded to cast immobilization followed by physical therapy, and there were no recurrences reported. ${ }^{34}$

All these findings indicate that it is important to find out whether there is one or more causes for posterior heel pain 
in young athletes to be able to provide the correct treatment. Even though Sever's disease is the most described cause of posterior heel pain, there might be other causes, solely or coexisting, like Achilles tendinitis/tendinopathy, plantar fasciitis, or retrocalcaneal bursitis that might affect the outcome and prognosis with treatment.

\section{Etiology}

There is a debate in the literature concerning what the cause of the heel pain really is and, also, if the problem can differ depending on age. If the hind foot is exposed to overload, one or more of its structures might get injured. As mentioned earlier, some common structures causing heel pain in young athletes are the calcaneus, Achilles tendon, plantar fascia, and retrocalcaneal bursa. The structure or structures that become injured can depend on a number of factors, including type of activity, foot biomechanics, age, physical maturity, motor skills, equipment, and playing surface. ${ }^{1,16,23}$ For heel pain, such as Sever's disease, also known as calcaneal apophysitis, the etiology is believed to be inflammation due to repetitive microtrauma from the pull of the Achilles tendon onto the calcaneus. ${ }^{5}$ Also, microcontusions caused by the impact from the heel strike are suggested to play a role. ${ }^{23,26}$ The microscopic pathophysiologic characteristics have not been fully detailed due to lack of data. ${ }^{12}$ Sever's disease appears to be most common before or during a child's growth spurt, usually occurring at the age 10-12 years in boys and 8-10 years in girls. ${ }^{5}$ During this period, long bone growth often exceeds muscle and tendon growth, which leads to less flexibility. ${ }^{16,32}$ During the next stage of puberty, children start to gain in muscle strength. Both these factors result in greater stress on the apophysis with weight-bearing activities. ${ }^{16}$ Other contributing extrinsic risk factors are believed to be overuse, such as when starting a new sport, at the beginning of a new season, or an increased activity level in general. ${ }^{5,23}$ High-impact sports involving running and jumping, improper footwear, and running on hard surfaces are other extrinsic risk factors proposed in the literature. ${ }^{5,23}$ Furthermore, suggested intrinsic risk factors are biomechanical abnormalities like flat foot, high arch, and overpronation. ${ }^{5}$ Being overweight is also an intrinsic risk factor reported by Sever as far back as $1912 .{ }^{35}$ Sever's disease is self-limiting and subsides after fusion of the apophysis, which takes place at around 15 years of age. ${ }^{16}$ After this, Sever's no longer occurs, and Achilles tendinopathy becomes a more common problem. ${ }^{4}$ The etiology of Achilles tendon pain is also considered to be multifactorial, with the same risk factors as described earlier. ${ }^{8,36}$ For retrocal- caneal bursitis, a suggested primary cause is compression by, for example, a tight shoe, or it may develop secondary to Achilles tendinopathy and plantar fasciitis. ${ }^{37}$ Because these conditions share many risk factors, it sometimes can be difficult to predict which structure will get hurt. Today the recommendation is to reduce the number of risk factors and in that way minimize overuse injuries causing heel pain. However, there is a need for prospective studies, using reliable and valid methods, to investigate further the etiology and risk factors for heel pain in young athletes.

\section{Diagnosis}

The diagnosis is made based on the clinical history and physical examination (Table 2). ${ }^{4,18,26,38}$ In some cases, imaging such as X-ray, ultrasound imaging, computed tomography scan (CT), or MRI are needed to rule out differential diagnoses or to confirm or complement the clinical examination. ${ }^{5}$ The varying types of imaging are useful for different types of structures. For example, an X-ray may find a fracture or neoplasm, whereas ultrasound imaging can give reliable information about the Achilles tendon insertion and the bone-cartilage interface at the calcaneal tuberosity. ${ }^{5,39} \mathrm{CT}$ and MRI may, for example, be needed to rule out conditions such as stress fracture, tarsal coalition, or osteomyelitis. ${ }^{5}$

Young athletes with Sever's disease often have a clinical history of sports involvement during their growth spurt. ${ }^{18}$ There may also be a direct trauma or injury to the heel involved. ${ }^{16}$ Pain is typically absent when the child awakens, but increases with activity and improves with rest. ${ }^{16}$ The heels are typically impact-sensitive, and the child may walk with a limp. ${ }^{26}$ During clinical examination, patients with Sever's disease often show tenderness to palpation at or just anterior to the insertion of the Achilles tendon along the posterior border of the calcaneus. ${ }^{16,35}$ The plantar fascia may also be tender..$^{32} \mathrm{~A}$ tight Achilles tendon and weakness of the ankle are symptoms often described in the literature. ${ }^{3}$ Passive dorsiflexion in patients with tight triceps surae often elicits pain. ${ }^{16}$ One study indicates that pain occurred bilaterally in $60 \%$ of patients, ${ }^{40,41}$ but in Kvist and Heinonen's study, ${ }^{26}$ only $15 \%$ had bilateral symptoms. A positive Sever's sign has been described in the literature as being when the child's pain is aggravated while standing on tiptoes. ${ }^{16}$ However, Sever ${ }^{35}$ and Hendrix ${ }^{5}$ describe that toe walking relieves the pain. Due to this discrepancy in the literature, we question the use of this test for determining the diagnosis. Another clinical evaluation method is the squeeze test whereby pain is induced by compressing medially and laterally on the posterior lower part of the heel. ${ }^{16}$ There may also be swelling and hardening 
of this area. ${ }^{3}$ X-ray should only be used when pain is odd in character or persists in spite of adequate treatment. ${ }^{26,38}$ There has been some disagreement as to whether sclerosis, which is seen as increased radiodensity and fragmentation in the apophyseal secondary ossification center, should be seen as an abnormal finding or not in the radiographic appearance. ${ }^{34}$ Liberson et $\mathrm{al}^{42}$ showed in a study that these findings can also be seen in asymptomatic feet, therefore concluding that sclerosis should be seen as a normal finding, and that fragmentation, which appeared more in patients with Sever's disease, should be suggestive but not diagnostic for Sever's disease. In a prospective study performed in 61 children, 10 with bilateral calcaneal apophysitis (mean age $10.43 \pm 1.21$ years), 70 feet had normal X-rays and one had a bone cyst present. ${ }^{38}$ Based on this, Kose ${ }^{38}$ concluded that neither sclerosis nor fragmentation could be used for diagnosis, and that a thorough history and clinical evaluation should be sufficient.

For Achilles tendinopathy, the cardinal symptom is pain localized in the Achilles tendon, which can range from slight pain only occurring for a short while after activity to intense pain on performing activities of daily living. ${ }^{36,43}$ Morning stiffness and pain on palpation are typical early signs. ${ }^{44}$ During clinical examination, there is tenderness over parts of the tendon and sometimes there might be swelling, while the musculotendinous junction and osteotendinous junction are often without pain. ${ }^{45}$ Both dorsiflexion and plantar flexion may elicit pain, especially if put under load. Sometimes a palpable nodule can be felt in the midportion of the tendon. ${ }^{46}$ Ultrasound imaging and MRI may show a thickening of the tendon and paratendon, and these changes often correspond to the area of tenderness. ${ }^{47}$

For retrocalcaneal bursitis, common symptoms are pain, sometimes localized swelling of the bursa, and, in rare cases, redness over the Achilles tendon insertion. ${ }^{37}$ Ultrasound imaging and MRI may show an increased quantity of fluid in the bursa. ${ }^{37}$

The clinical findings for plantar fasciitis are pain with weight-bearing which is localized underneath the foot where the plantar fascia attaches to the calcaneus. ${ }^{37}$ Morning stiffness is often present. In simple cases, the pain is only present at the beginning of exercise and in the morning, but in the more severe cases, pain is present during every step. Gradually increasing symptoms are typical. During palpation, the patient complains of pain in the area of insertion of the fascia at the calcaneus. ${ }^{37} \mathrm{X}$-ray may show a heel spur, but this is not diagnostic because these also occur in asymptomatic people. ${ }^{37}$

\section{Treatment}

Numerous articles have described various types of treatments for heel pain in children, including stretching, strengthening exercises, limiting physical activity and sports participation, ice, heel lifts for removal of tensile forces on the calcaneus, correction of malalignment through orthotic use, and even anti-inflammatory drugs. However, none of these have been evaluated in prospective treatment trials with validated outcome measures. . $3-5,16,18,19,22,23,25,26,28,29,31,32,40,48,49$ Often the recommendations are for various combinations of the aforementioned treatments. Other more unusual treatments mentioned in the literature include avoidance of walking barefoot, and use of night splints, a cast, and/or crutches. ${ }^{3,16,25,31,40}$ Most of the recommendations are based on the clinical experience of the authors, or are just a summary of what previous studies have recommended. We have found no prospective randomized clinical trials comparing various treatments for this patient population. In retrospective studies, the authors report on the success of treatment; however, the treatments are mostly generally described, including strengthening, stretching, orthotics, and activity modifications, with minimal information regarding outcomes using these measures..$^{9,18,22}$ If the diagnosis includes retrocalcaneal bursitis and pain with pressure, then the treatment mostly is focused on modifying footwear. ${ }^{37}$ In the adult patient with a painful Achilles tendon (Achilles tendinopathy), eccentric exercise has been shown to be effective, but whether or not this treatment is successful in children has not been evaluated. ${ }^{7}$ However, there appears to be a consensus in the literature that surgery should rarely be considered as a treatment option, due to the self-limiting nature of the condition in children and adolescents. ${ }^{16,25}$

Because the treatment recommendations are mostly a concoction of various strategies initiated simultaneously, it is difficult to know what the benefits are from each individual component. The concerns with these broad recommendations are that they are not individualized to the patient, and the theory and reasoning behind each treatment strategy is not considered. Therefore, we will discuss the theory and mechanism behind each of the most commonly suggested conservative treatment strategies and relate these to this patient group to provide a more thorough understanding of the potential effects of treatment. However, further research needs to be performed on each of the various treatment strategies.

\section{Stretching}

Stretching of the calf musculature is one of the main suggestions for treatment regardless of whether the symptoms 
come from the heel or from the Achilles tendon. ${ }^{4,9,17,18,22}$ If the patients have been through a growth spurt prior to developing symptoms, the muscle-tendon unit might not have adjusted to the increased skeletal length. ${ }^{15}$ This would then result in a tight calf musculature and Achilles tendon, along with a decreased range of motion in ankle dorsiflexion. In the literature, this increased tightness is suggested to cause a pull at the calcaneal insertion. ${ }^{5,9}$ Stretching is then prescribed as a treatment to alleviate this. However, there is a lack of description and objective measurement in the literature regarding whether the patients actually have a decreased range of motion in dorsiflexion, and if achieving an increased range of motion decreases symptoms. ${ }^{9,18,22}$ Studies have shown that range of motion in ankle dorsiflexion can be increased with stretching by approximately one degree, but the actual increase might be just due to increased stretch tolerance and not due to increased compliance and/or lengthening of the muscle-tendon complex. ${ }^{50}$ Often the patients have pain when the ankle is at the end range of dorsiflexion, so stretching in this position might instead aggravate the symptoms. This might be especially true if the insertional site is the weaker link, as described in the literature. ${ }^{4,5}$ Recent studies have also found that stretching might negatively affect the ability of muscle to generate force. ${ }^{51}$ If the muscle-tendon complex is already stretched due to growth, weakness of the calf musculature might be of greater concern. Whether stretching in this patient population actually promotes increased range of motion and relieves symptoms need to be further investigated. Our recommendation is that a thorough evaluation needs to be performed, and stretching should be considered as a treatment only if there is a range of motion deficits. The effectiveness may also vary depending on the age and growth status of the patient. Follow-up evaluations to determine the patient's response to the treatment is therefore of great importance.

\section{Strengthening}

Recommendations for strengthening both the ankle dorsiflexors and plantar flexors are found in the literature. , $9,17,18,22^{2}$ Again, most studies lack description regarding whether strength evaluations were performed and if any strength deficits could be found. The ankle plantar flexor muscles control the amount of dorsiflexion at the ankle during walking, running, and jumping activity, and are active during push-off, propelling the body forward/upward. ${ }^{52}$ Weakness of the plantar flexors can cause excessive dorsiflexion, which might then cause irritation at the insertional site of the Achilles tendon. Several authors describe exercises such as heel rises (especially eccentric heel rises standing on a step) because these have been shown to be effective in adults. ${ }^{7,17,18}$ However, we feel one has to be careful with applying this treatment model in the young patient for two reasons. Performing exercises standing on stairs often promotes excessive dorsiflexion which can actually irritate the insertion. For adults with insertional pain, it has been found that performing the exercises on a flat floor is better. ${ }^{53}$ Furthermore, the calf muscle is active both concentrically and eccentrically during daily activities, and it therefore seems important to perform strengthening using both types of muscle contractions. ${ }^{52}$ Therefore, we recommend both concentric and eccentric heel rises (Figure 2). The starting position is standing flat on the floor, or even with a book under the heel (Figure 3) if it is painful to lift the heel from a flat surface. If weakness is found in other muscles around the foot, ankle, and knee, we recommend strengthening exercises for these areas as well. Again, further studies are needed to determine if these patients have weakness, and to determine if strengthening exercises have an effect on the patient symptoms and ability to be physically active.

\section{Heel lift and orthotics}

Often a heel lift is recommended to be placed in the shoe. ${ }^{4,9,17,18,22}$ The purpose of the heel lift is to place the ankle in a slight plantar-flexed position which would alleviate some of the pull and compression of the Achilles tendon onto the calcaneus. This is often described to result in decreased symptoms and can be used as long as it provides pain relief. ${ }^{3,5,17,18}$ In some sports, such as soccer, where shoes are very flat, use of a heel lift might be of greater benefit compared with, for example, a
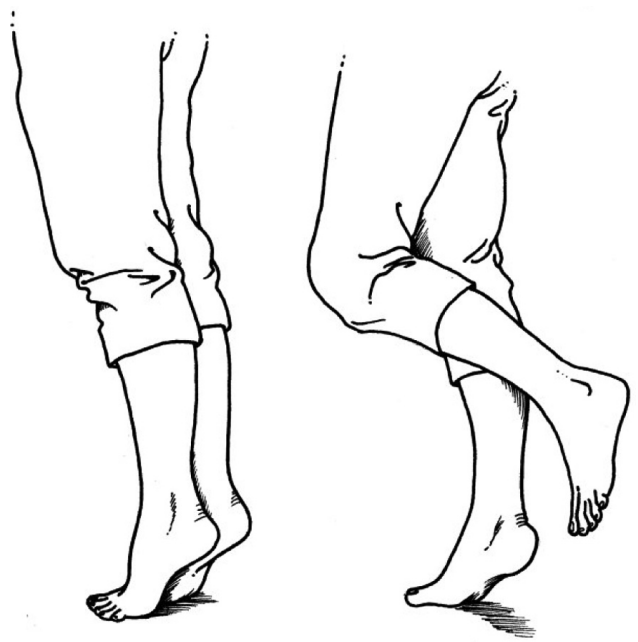

Figure 2 Two-legged or one-legged heel-rise. Going up onto the toes is a concentric calf muscle contraction and lowering the heel down to the floor is an eccentric calf muscle contraction. 


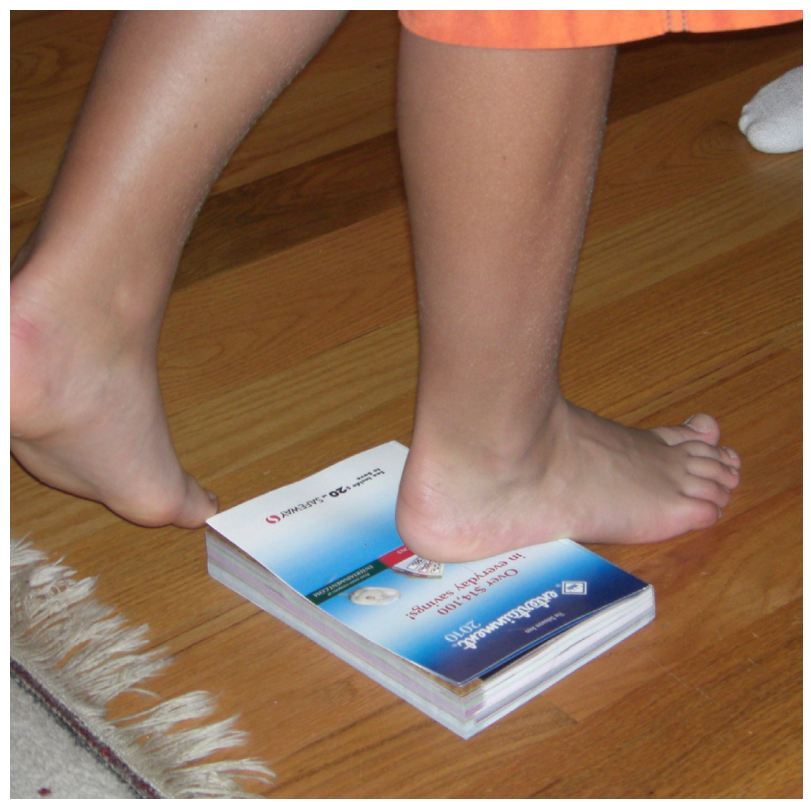

Figure 3 Starting position of a heel rise, with a book under the heel, if painful to start with the heel on the floor.

running shoe, which usually has a higher heel. Custom-made insoles might also be good for certain patients if biomechanical malalignment exists. However, it is important that the patient is thoroughly evaluated, and orthotics should only be used if there are abnormal lower extremity mechanics and alignment exits which cannot be improved through rehabilitation.

\section{Activity modification and return to sport}

Because heel-pain in young athletes has been attributed to increased activity, such as that occurring at the beginning of the sport season, some kind of activity modification is often recommended. 4,9,17,18,22 The level of pain and symptoms are often used as a guide when determining the appropriate level of activity participation. ${ }^{10,54}$ For adults, a pain-monitoring model (Figure 4) has been used successfully to grade exercises and return to sport in patients with Achilles tendinopathy and patellofemoral pain syndrome. ${ }^{10,54,55}$ This has not been evaluated for young athletes with heel pain, but it is a very useful tool for the patient, doctor, and parents when determining the appropriate activity level. (See Figure 4 for specifics regarding the pain-monitoring model). In the literature it is usually recommended that the young athlete initially rests from sports participation and, when the pain subsides, a gradual progression back into full sports participation is advised. 4,17,22 Again, because it is important for a child's health to be physically active, we feel it is important to not just recommend cessation of all physical activity,

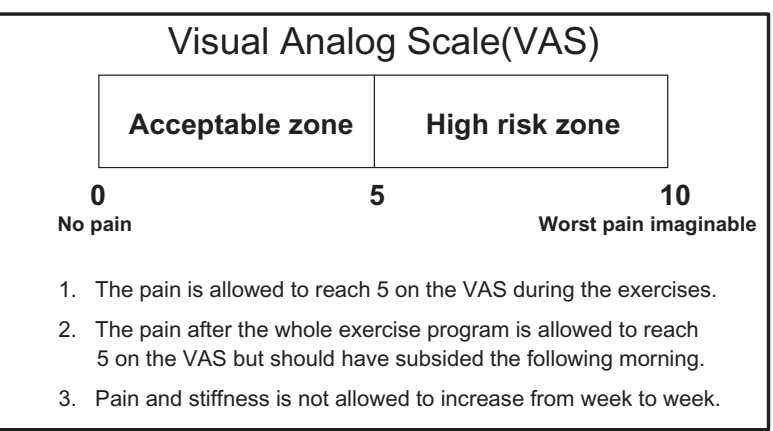

Figure 4 Pain-monitoring model.

but instead recommend participation in activities that impart less load to the heel, such as swimming or cycling.

\section{Prevention of injury and reinjury}

Finding and adjusting intrinsic and extrinsic risk factors are crucial for the success of prevention and treatment of any type of overuse injury, regardless of the patient's age..$^{18,37}$ There is a void in the literature concerning research that has prospectively studied the risk factors for developing posterior heel and Achilles tendon pain in young athletes. Therefore, we are presently unable to determine if the possible weakness and decreased range of motion seen is due to the pain/injury or if it is a cause of the development of pain/injury. To make a specific recommendation for a preventative exercise program is difficult. However, because heel and Achilles tendon pain often occurs in combination with increased training activity, a discussion on how young athletes should train is warranted. ${ }^{22}$ The maturity and body size of young athletes can vary considerably, even though they are of the same age. What is an appropriate level of training for one athlete might be too high for another, placing that athlete at an increased risk for overuse injury. Therefore, monitoring the individual athlete's symptoms and pain is of great importance when returning to training in this patient population. A gradual progression of training in regards to frequency, intensity, and type of activity needs to be individualized for each patient, in consultation with parents and coaches. Prospective studies on risk factors for heel and Achilles tendon pain in the young athlete is of great importance, and is necessary prior to being able to make specific recommendations.

\section{Prognosis}

The young athlete is not recommended to return to sporting activity until symptoms allow comfortable participation. ${ }^{16,17}$ The literature suggests that, with proper intervention, most patients with Sever's disease are able to return to sports 
within a few weeks to two months. ${ }^{16-18}$ This is supported by a retrospective questionnaire of 67 patients with Sever's disease where the patients reportedly were forced to stop training because of pain for an average of 1.3 months (less than two weeks in $55 \%$ of the patients). ${ }^{26}$ However, the recurrence rate of Sever's disease was $28 \%$ in a group of patients who had been symptom-free for two months. Interestingly, $48 \%$ of the patients with a diagnosis of Sever's disease also developed Osgood-Schlatter's disease. ${ }^{26}$ This is more then twice the incidence $(21.2 \%)$ reported in adolescents active in sports. ${ }^{56}$ Furthermore, one study ${ }^{18}$ stated that, on rare occasions, it has taken up to six months to recover from Sever's disease, whereas others have reported that, in some cases, the pain could continue until growth ceases. ${ }^{29}$ Chronic resistant cases are described to be those that present with bony lesions or symptoms in the Achilles tendon. ${ }^{28}$ Studies state that recurrent episodes are probable until about 15 years of age, but that the condition is self-limiting and will disappear when the child stops growing. ${ }^{26,32,48}$ Due to the lack of prospective long-term follow-up studies, it is not known if all the young athletes actually do return to their sport of choice or if they discontinue running and jumping activity due to pain. Whether or not the current recommended treatments are effective in providing pain relief and enabling return to sport in both the short term and long term needs to be investigated further.

\section{Conclusion}

In summary, it is important to perform a thorough evaluation of every young athlete with heel and Achilles tendon pain to make the appropriate diagnosis, treat the deficits found, and allow for a gradual progression to training. However, the recommendations today are based on clinical experience and a few retrospective studies, and further well-designed prospective studies with validated outcome measures are urgently needed for the young athlete.

\section{Disclosure}

The authors report no conflicts of interest in this work.

\section{References}

1. Adirim TA, Cheng TL. Overview of injuries in the young athlete. Sports Med. 2003;33(1):75-81.

2. Pommering TL, Kluchurosky L, Hall SL. Ankle and foot injuries in pediatric and adult athletes. Prim Care. 2005;32(1):133-161.

3. Malanga GA, Ramirez-Del Toro JA. Common injuries of the foot and ankle in the child and adolescent athlete. Phys Med Rehabil Clin N Am. 2008;19(2):347-71, ix.

4. Micheli L, Fehlandt A. Overuse injuries in pediatric sports medicine. Sports Med Arthrosc. 1996;4:190-195.
5. Hendrix CL. Calcaneal apophysitis (Sever disease). Clin Podiatr Med Surg. 2005;22(1):55-62, vi.

6. Magnussen RA, Dunn WR, Thomson AB. Nonoperative treatment of midportion Achilles tendinopathy: A systematic review. Clin J Sport Med. 2009;19(1):54-64.

7. Kingma JJ, de Knikker R, Wittink HM, Takken T. Eccentric overload training in patients with chronic Achilles tendinopathy: A systematic review. Br J Sports Med. 2007;41(6):e3.

8. Kaufman KR, Brodine SK, Shaffer RA, Johnson CW, Cullison TR. The effect of foot structure and range of motion on musculoskeletal overuse injuries. Am J Sports Med. 1999;27(5):585-593.

9. Scharfbillig RW, Jones S, Scutter SD. Sever's disease: What does the literature really tell us? J Am Podiatr Med Assoc. 2008;98(3):212-223.

10. Silbernagel KG, Thomee R, Eriksson BI, Karlsson J. Continued sports activity, using a pain-monitoring model, during rehabilitation in patients with Achilles tendinopathy: A randomized controlled study. Am J Sports Med. 2007;35(6):897-906.

11. Rompe JD, Nafe B, Furia JP, Maffulli N. Eccentric loading, shock-wave treatment, or a wait-and-see policy for tendinopathy of the main body of tendo Achilles: A randomized controlled trial. Am J Sports Med. 2007;35(3):374-383.

12. Walling A, Carty C, Grogan D. Fracture of the calcaneal apophysis. J Orthop Trauma. 1990;4:349-355.

13. Józsa L, Kannus P. Human Tendons. Anatomy, Physiology and Pathology. Champaign, IL: Human Kinetics; 1997.

14. Ghazzawi A, Theobald P, Pugh N, Byrne C, Nokes L. Quantifying the motion of Kager's fat pad. J Orthop Res. 2009;27(11):1457-1460.

15. Omey ML, Micheli LJ. Foot and ankle problems in the young athlete. Med Sci Sports Exerc. 1999;31Suppl 7:S470-S486.

16. Madden CC, Mellion MB. Sever's disease and other causes of heel pain in adolescents. Am Fam Physician. 1996;54(6):1995-2000.

17. Kim CW, Shea K, Chambers HG. Heel pain in children. Diagnosis and treatment. J Am Podiatr Med Assoc. 1999;89(2):67-74.

18. Micheli LJ, Ireland ML. Prevention and management of calcaneal apophysitis in children: An overuse syndrome. J Pediatr Orthop. 1987; 7(1):34-38.

19. Hogan KA, Gross RH. Overuse injuries in pediatric athletes. Orthop Clin North Am. 2003;34(3):405-415.

20. Cassas KJ, Cassettari-Wayhs A. Childhood and adolescent sportsrelated overuse injuries. Am Fam Physician. 2006;73(6):1014-1022.

21. Järvinen TA, Kannus $P$, Paavola M, Järvinen TL, Jozsa L, Järvinen M. Achilles tendon injuries. Curr Opin Rheumatol. 2001;13(2): 150-155.

22. Micheli LJ, Fehlandt AF Jr. Overuse injuries to tendons and apophyses in children and adolescents. Clin Sports Med. 1992;11(4):713-726.

23. Bartold S. Heel pain in young athletes. Aust Podiatr. 1993;27: 103-105.

24. Kvist M, Alanen J, Levola J. The complaints of lower extremities in children and their relation to foot structure and physical activity. Presented at the International Congress on Applied Research in Sports, Helsinki, Finland, 1994 Aug 9-11.

25. Manusov EG, Lillegard WA, Raspa RF, Epperly TD. Evaluation of pediatric foot problems: Part II. The hindfoot and the ankle. Am Fam Physician. 1996;54(3):1012-1026, 1031.

26. Kvist M, Heinonen O. Calcaneal apophysitis (Sever's disease) - a common cause of heel pain in young athletes. Scand J Med Sci Sports. 1991;1:235-238.

27. Meyerding H, Stuck W. Painful heels among children. JAMA. 1934; 102:1658.

28. Subotnick S. Sports Medicine of the Lower Extremity. 2nd ed. New York, NY: Churchill-Livingstone; 1989.

29. Sammarco HCG. Persistent foot and ankle pain in young athletes. Phys Sportsmed. 1995;23:67-74.

30. Kaeding C, Whitehead R. Musculoskeletal injuries in adolescents. Prim Care. 1998;25(1):211-223.

31. Lewin P. Apophysitis of the os calcis. Surg Gynecol Obstet. 1925;41: 579-582. 
32. Topham JWA. Clinical profiles, Sever's disease. Phys Ther Case Rep. 1998;1(3):160-161.

33. Hosgören B, Koktener A, Dilmen G. Ultrasonography of the calcaneus in Sever's disease. Indian Pediatr. 2005;42(8):801-803.

34. Ogden JA, Ganey TM, Hill JD, Jaakkola JI. Sever's injury: A stress fracture of the immature calcaneal metaphysis. J Pediatr Orthop. 2004; 24(5):488-492.

35. Sever J. Apophysitis of the os calcis. New York Med J. 1912;95: 1025-1029.

36. Kader D, Saxena A, Movin T, Maffulli N. Achilles tendinopathy: Some aspects of basic science and clinical management. Br J Sports Med. 2002;36(4):239-249.

37. Thomas JL, Christensen JC, Kravitz SR, et al. The diagnosis and treatment of heel pain: A clinical practice guideline-revision 2010. J Foot Ankle Surg. 2010;49 Suppl 3:S1-S19.

38. Kose O. Do we really need radiographic assessment for the diagnosis of non-specific heel pain (calcaneal apophysitis) in children? Skeletal Radiol. 2009;39(4):359-361.

39. Grechenig W, Mayr JM, Peicha G, Hammerl R, Schatz B, Grechenig S. Sonoanatomy of the Achilles tendon insertion in children. $J$ Clin Ultrasound. 2004;32(7):338-343.

40. Peck DM. Apophyseal injuries in the young athlete. Am Fam Physician. 1995;51(8):1891-1895.

41. Micheli LJ. The traction apophysitises. Clin Sports Med. 1987;6(2): 389-404.

42. Liberson A, Lieberson S, Mendes DG, Shajrawi I, Ben Haim Y, Boss JH. Remodeling of the calcaneus apophysis in the growing child. J Pediatr Orthop B. 1995;4(1):74-79.

43. Maffulli N, Sharma P, Luscombe KL. Achilles tendinopathy: Aetiology and management. J R Soc Med. 2004;97(10):472-476.

44. Maffulli N, Khan KM, Puddu G. Overuse tendon conditions: Time to change a confusing terminology. Arthroscopy. 1998;14(8):840-843.

45. Alfredson H. Chronic midportion Achilles tendinopathy: An update on research and treatment. Clin Sports Med. 2003;22(4):727-741.
46. Longo UG, Ronga M, Maffulli N. Achilles tendinopathy. Sports Med Arthrosc. 2009;17(2):112-126.

47. Movin T, Kristoffersen-Wiberg M, Shalabi A, Gad A, Aspelin P, Rolf C. Intratendinous alterations as imaged by ultrasound and contrast mediumenhanced magnetic resonance in chronic achillodynia. Foot Ankle Int. 1998;19(5):311-317.

48. Tollafield DR, Merriman DT. Clinical Skills in Treating the Foot. London: Churchill Livingstone; 1997.

49. Crosby L, McMullen S. Heel pain in active adolescents? Consider calcaneal apophysitis. Phys Sportsmed. 1993;21:89-91.

50. Park DY, Chou L. Stretching for prevention of Achilles tendon injuries: A review of the literature. Foot Ankle Int. 2006;27(12):1086-1095.

51. McHugh MP, Cosgrave CH. To stretch or not to stretch: The role of stretching in injury prevention and performance. Scand J Med Sci Sports. 2010;20(2):169-181.

52. Mann RA, Hagy J. Biomechanics of walking, running, and sprinting. Am J Sports Med. 1980;8(5):345-350.

53. Jonsson P, Alfredson H, Sunding K, Fahlstrom M, Cook J. New regimen for eccentric calf-muscle training in patients with chronic insertional Achilles tendinopathy: Results of a pilot study. Br J Sports Med. 2008; 42(9):746-749.

54. Thomeé R. A comprehensive treatment approach for patellofemoral pain syndrome in young women. Phys Ther. 1997;77(12):1690-1703.

55. Silbernagel KG, Thomeé R, Thomeé $P$, Karlsson J. Eccentric overload training for patients with chronic Achilles tendon pain - a randomised controlled study with reliability testing of the evaluation methods. Scand J Med Sci Sports. 2001;11(4):197-206.

56. Kujala UM, Kvist M, Heinonen O. Osgood-Schlatter's disease in adolescent athletes. Retrospective study of incidence and duration. Am J Sports Med. 1985;13(4):236-241.
Open Access Journal of Sports Medicine

\section{Publish your work in this journal}

Open Access Journal of Sports Medicine is an international, peer-reviewed, open access journal publishing original research, reports, reviews and commentaries on all areas of sports medicine. The manuscript management system is completely online and includes a very quick and fair peer-review system.

\section{Dovepress}

Visit http://www.dovepress.com/testimonials.php to read real quotes from published authors. 